This is an author generated post-print of the article:

Sorte, S., Rodrigues, V., Ascenso, A., Freitas, S., Valente, J., Monteiro, A., Borrego, C., 2018.

Numerical and physical assessment of control measures to mitigate fugitive dust emissions from harbor activities. Air Quality, Atmosphere and Health 11, 493-504.

The final publication is available on https://doi.org/10.1007/s11869-018-0563-7 


\title{
Numerical and physical assessment of control measures to mitigate fugitive dust emissions from harbor activities
}

\author{
Sandra Sorte ${ }^{\mathrm{a} *}$, Vera Rodrigues $^{\mathrm{a}}$, Ana Ascenso ${ }^{\mathrm{a}}$, Sylvio Freitas ${ }^{\mathrm{a}}$, Joana Valente $^{\mathrm{a}}$, Alexandra \\ Monteiro $^{\mathrm{a}}$, Carlos Borrego ${ }^{\mathrm{a}}$ \\ a CESAM \& Department of Environment and Planning, University of Aveiro, 3810-193 Aveiro, Portugal. \\ *Corresponding author: ssss@ua.pt, Tel: +351 234370220, Fax: +351 234370309
}

\begin{abstract}
In recent years, the industrial demand for petcoke - a solid residue derived from the refinement of crude oil - has been growing due to its low cost. The use of petcoke is causing environmental concern associated with its high level of contaminants and air pollutant emissions, mainly particulate matter (PM). Given the impact of petcoke on the environment and human health, increased attention has been given to its production, storage, transportation and application processes. The main goal of this work was to assess the effectiveness of placing a barrier to reduce PM emissions from petcoke in a harbor area. The Port of Aveiro, Portugal, was used as case study. Firstly, wind tunnel experiments were performed for different types of barrier to (i) assess the effect on PM emissions of different types of barriers, namely solid, porous and raised porous barriers, (ii) determine the optimal size and location of the barrier to achieve maximum reduction of PM emissions, and (iii) estimate the impact of placing such barrier in the attenuation of petcoke emissions over the harbor area. Secondly, the numerical model VADIS was run to evaluate the effect of implementing the barrier on the local air quality. Results showed that the best solution would be the implementation of two solid barriers: a main barrier of $109 \mathrm{~m}$ length plus a second barrier of $30 \mathrm{~m}$ length. This measure produced the best results in terms of reduction of the dispersion of particulate matter from the petcoke stockpile and minimization of the PM concentrations in the harbor surrounding area.
\end{abstract}

KEYWORDS: Petcoke; particulate matter emissions; wind tunnel; CFD; barrier implementation.

\section{Introduction}

Recently, emissions from maritime transport have become an important air quality issue, raising interest among the scientific community, stakeholders and decision makers, in particular for ports surrounded by high-density residential areas (Contini et al. 2015; Guttikunda et al. 2015; Balakrishnan et al. 2013). According to the European Sea Ports Organization, the top environmental priority for seaports is the local air quality, reflecting its importance on the health of port workers and nearby residents (ESPO 2013). Detailed knowledge about the type of emissions from shipping remains scarce (Healy et al. 2009), encompassed by the lack of 
experimental data quantifying the contribution of ship's emissions to local air quality (Isakson et al. 2001; Borrego et al. 2007). Marine vessels' emissions come primarily from diesel engines operating on oceangoing vessels, tugs and tows, dredges, and other vessels operating within a port area. Land-based emission sources include essentially cargo handling equipment. Emissions from cargo unloading and handling activities are also considered, since they have an important contribution for the total emissions (Schrooten et al. 2008; Song 2014).

Petroleum coke (petcoke) is a granular residue that poses considerable threat to the environment and human health. It is a dark solid material composed primarily of carbon, usually showing limited amounts of elemental forms of sulfur, non-volatile inorganic compounds and heavy metals, such as vanadium (V) or nickel (Ni) (USEPA 2015; Mckee et al. 2014). Petcoke is generally stable under normal conditions and chemically inert; however, it has the potential to become flammable or explosive in enclosed spaces (Caruso et al. 2015). In 2014, petcoke accounted for almost $30 \%$ of the materials loaded, unloaded and handled in the North Portuguese harbors. Due to its relatively low cost when compared to coal, it supplies energy for industrial combustion processes such as cement manufacturing (CRS 2013). There is a growing global demand for the supply of petcoke in a vast array of industries. Thus, outdoor storage in stockpiles in harbors is becoming a common practice, even in harbors located in the surroundings of urban communities. In such cases, fugitive dust emissions from petcoke endanger the local population's health (Grahame and Schlesinger, 2010). Moreover, petcoke particles may also have negative impact on buildings (Dourson et al. 2016; USEPA 2015).

There is still a lack of understanding concerning health and environmental effects of fugitive petcoke dust and most authors agree that further investigation is an important requirement (e.g. Dourson et al. 2016), especially considering that petcoke production and usage continue to increase.

Toxicological studies performed recently suggested that petcoke acts generally, as an inert dust with human health risks associated to high-level or long-term dust inhalation, such as chronic pulmonary inflammation or respiratory tract irritation (Caruso et al. 2015; USEPA 2015; Mckee et. 2014). According to the EEA (2013) components of PM such as heavy metals or PAH (polycyclic aromatic hydrocarbons), which are contained in petcoke, are known carcinogens and directly toxic to living cells. Keil et al. (2016) reported a reduction of the immunoglobulin-M antibody production, while Salnikow et al. (2004) found that the inhalation of Ni present in petcoke and residual oil fly ash leads to hypoxic stress and induces the secretion of proinflammatory cytokine.

Studies performed by the US Environmental Protection Agency have reported that petcoke dust has negligible biodegradation in soils, atmospheric photo-oxidation and volatilization, being also poorly soluble in aquatic environments with neutral pH (USEPA 2015). Caruso et al. (2015) 
studied the effect of pelleted petcoke in water (at 1 g.L. $\mathrm{L}^{-1}$ loadings) and reported a $7.1 \%$ inhibition on algae growth, although no adverse effects on aquatic invertebrates or fish were recorded. Increase in the concentration of heavy metals in the aquatic environment due to petcoke leaching was also reported, with noteworthy effects to local aquatic species (Caruso et al. 2015; Puttaswamy et al. 2014). Baker et al. (2012) analyzed trace metals in wetlands constructed using petcoke and other consolidated waste sediments in the Alberta tar sands (Canada), founding high concentrations of $\mathrm{Ni}$ and $\mathrm{V}$, attributed to petcoke, at levels that are toxic to local invertebrate species. Their results supported the findings of Puttaswamy et al. (2014), who found high levels of $\mathrm{Ni}$ and $\mathrm{V}$ in leachates collected from shallow and deep lysimeters in the same region. Both lysimeters were buried in petcoke and covered in glacial till (deep lysimeter) or peat (shallow lysimeter), and the concentrations measured were toxic to freshwater species.

Petcoke's dispersion rate depends not only on the meteorological conditions of the storage place but also on the intrinsic characteristics of the material, namely moisture content, size, density and mechanical properties (Roskill 2015).

Fugitive petcoke dust emissions can be minimized through the application of obstacles, such as walls, fences or shrubs, upwind from the petcoke piles, which is a realistic and relatively low-cost approach in reducing emissions. Novak et al. 2015 suggested that changing pile arrangement space as well as pile configuration could reduce dust emissions in the open storage yard. Increasing of the particles' moisture content may also reduce fugitive dust emissions.

This work aimed to find control measures that can mitigate fugitive dust petcoke emissions from harbor activities. The main goal was to find a way to minimize the impact of those petcoke emissions on the communities in the harbors' neighborhood. A real situation involving a Portuguese port area was studied, focusing on the implementation of real scale control measures, which is one of the main features of this work.

The work is structured as follows: Section 2 describes the case study framework; Section 3 and 4 describe the study of the type of barrier and its optimum location; assessment of local air quality using a CFD model is discussed in Section 5. The summary and conclusions are given in Section 6.

\section{Case study framework}

With 350 m of quays and 15 ha of embankments, the Solid Bulk Terminal (SBT) at the port of Aveiro is prepared with appropriate handling equipment with crane capacity up to 120 tonnes. A movement of about 2 million tonnes is recorded, with large areas dedicated to uncovered and covered storage of materials. In 2014, the administration of the port of Aveiro (APA) handled 424 ton of petcoke in its SBT, which corresponds to a $1.5 \%$ increase when compared to the previous year. Due to its proximity to one of Portugal's main cement production plants, Port of Aveiro's SBT is one of the country's major petcoke entry points. The port is located in the vicinity of 
Aveiro, within the town of Gafanha da Nazaré, which has a population around 15000 inhabitants. The nearest residential area is located at approximately $1 \mathrm{~km}$ to the south of the Port of Aveiro's SBT $\left(40^{\circ} 38^{\prime} 77.89^{\prime \prime} \mathrm{N}, 8^{\circ} 41^{\prime} 33.45^{\prime}\right.$ 'W). The location of the port and of this urban community is shown in Figure 1.

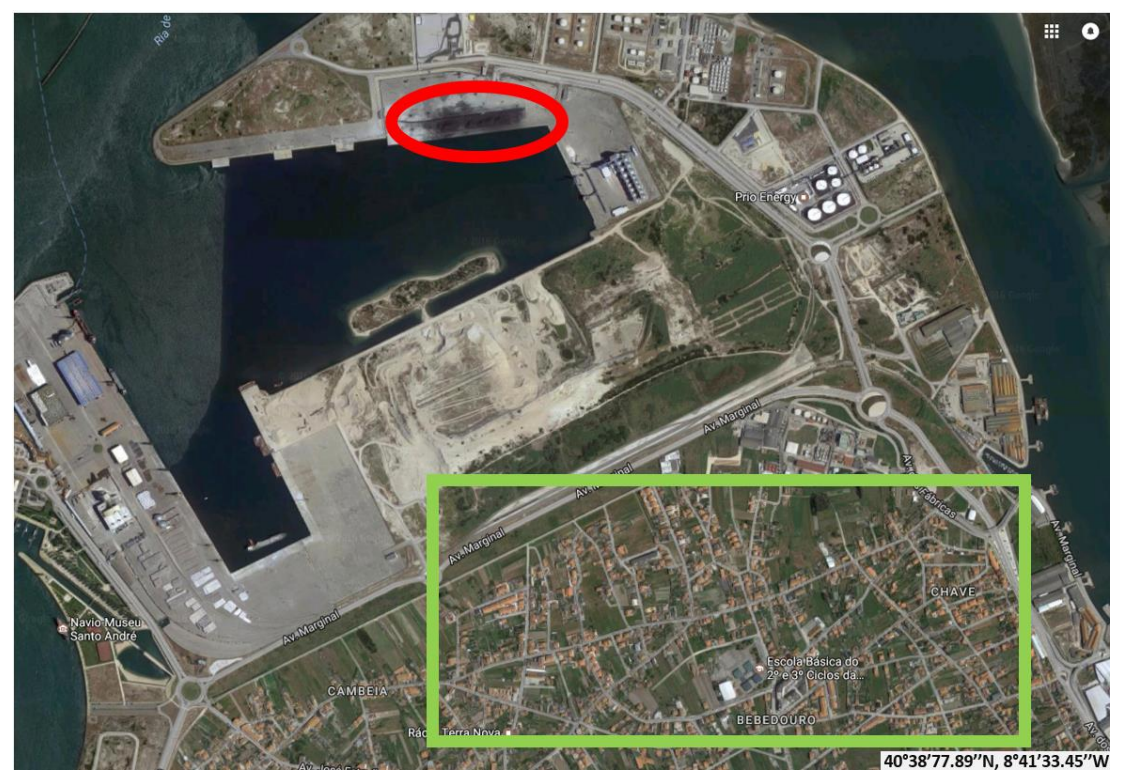

Figure 1. Study region: Gafanha da Nazaré (green rectangle), and the SBT of the Port of Aveiro (red circle), at $1 \mathrm{~km}$ of distance.

To characterize the typical meteorological conditions of the studied area, an analysis of meteorological data (namely wind data) was performed using hourly data from an 8 years period (2006-2013) recorded at the University of Aveiro's meteorological tower.

This meteorological tower is located roughly $5 \mathrm{~km}$ southwest from the studied area $\left(40^{\circ} 38^{\prime} 07.37^{\prime \prime} \mathrm{N}, 8^{\circ} 39^{\prime} 35.06^{\prime \prime} \mathrm{W}\right)$. This tower is representative of the surrounding environment (25 $\mathrm{km})$, belonging to the national meteorological monitoring network. Figure 2 shows the wind rose obtained from the data measured at $10 \mathrm{~m}$ height. 


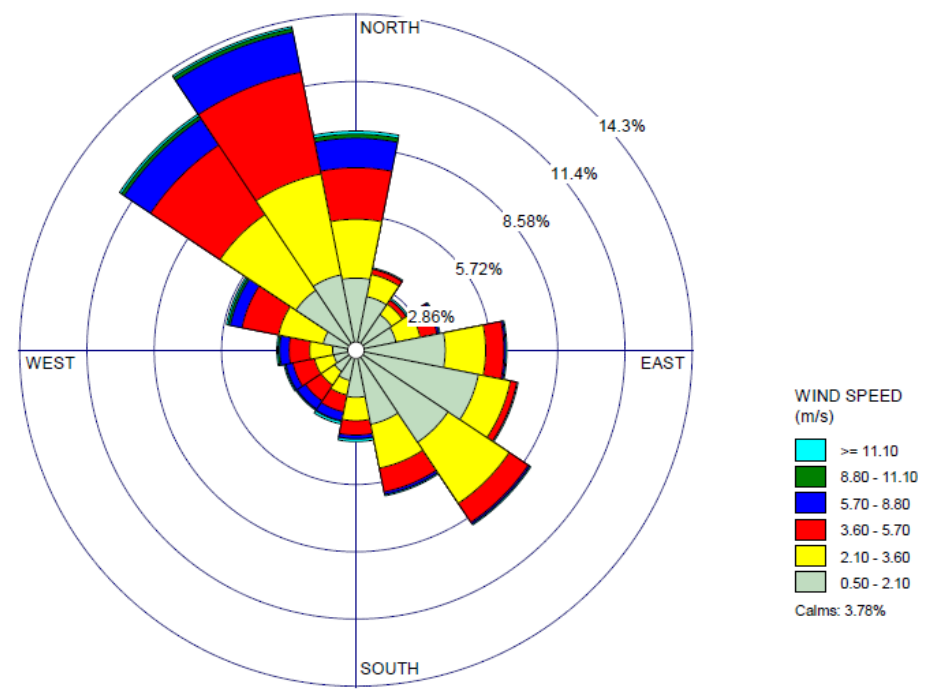

Figure 2. Wind rose for 2006-2013, obtained from measurements performed at $10 \mathrm{~m}$ height in the Meteorological Tower of the University of Aveiro.

Typically, the wind blows from the second and fourth quadrant, mainly from Northwest (NW), North $(\mathrm{N})$ and Southeast (SE) directions. Mean wind speeds range typically from $0.5 \mathrm{~m} \cdot \mathrm{s}^{-1}$ up to $11 \mathrm{~m} \cdot \mathrm{s}^{-1}$. N and NW winds were recorded during approximately $35 \%$ of the measurement time. The nearest urban communities to the Port of Aveiro are located South (S) and Southeast (SE) from the port, thus the wind directions that may affect the populations are in the $4^{\text {th }}$ quadrant (WN quadrant).

Over the last years, the residents of this urban community have reported high quantities of black dust in and around their residences, during handling and storage of petcoke in the SBT. These episodes lead to the necessity of evaluating the impacts of the different port activities in the surrounding environment. To assess the contribution of petcoke unloading and handling operations to the air pollution problems in the residential area near the port of Aveiro, a 90-days monitoring campaign was set up. The campaign performed by the Institute of Development and Environment included three air quality monitoring periods (30 days each): one during the winter (December 19th 2014 to January 20th 2015), one in the summer (July 2nd to August 1st 2014) and one in the spring (May 5th to June 4th 2015). During the three measurement periods, several arrivals of cargo ships carrying petcoke were registered, meaning that petcoke was handled in the SBT during about $70 \%$ of the measurement time. Each cargo ship transported between 6000 and 10000 tonnes of petcoke, which were unloaded and stored in stockpiles at the SBT (Sorte et al. 2018). PM10 measurements showed that the daily concentration limit of $50 \mu \mathrm{g} . \mathrm{m}^{-3}$, established by the European Air Quality Directive 2008/50/EC, was surpassed in 21 of the 90 monitoring days (Sorte et al. 2018). According to the legislation, concentration of PM10 may exceed the legal limit a maximum of 35 times per year. Considering the sampling period, the number of exceedances of the daily limit to the human health protection that would be critical was computed 
to be 8 . This means that the established daily limit value of $50 \mu \mathrm{g} \cdot \mathrm{m}^{-3}$ should not be surpassed more than 8 times to ensure proper human health protection. This limit was exceeded in all measurement periods. Moreover, the average concentration of PM10 was $45 \mu \mathrm{g} . \mathrm{m}-3$, indicating potential influence of Port activities. Exceedances of the limit value for PM10 concentration matched the petcoke movements in the SBT; this campaign was conducted under the influence of dominant Northwest winds. This was an important feature since the most common wind directions that affect the residential area blow from the West-North quadrant. Thus, the monitoring campaign was performed under the most critical situation in terms of dispersion of particles reaching the port's neighbor urban area (IDAD 2015).

During the measurement campaigns, the levels of $\mathrm{V}$ and $\mathrm{Ni}$ were also monitored. The highest average concentrations of 3.9 ng. $\mathrm{m}^{-3}(\mathrm{~V})$ and $10.4 \mathrm{ng} \cdot \mathrm{m}^{-3}(\mathrm{Ni})$ were reported at the closest location from the SBT during the winter measurement period (predominant winds from the SE direction). Although there is a correlation between the PM10 concentrations and petcoke movement activities, monitoring of $\mathrm{Ni}$ and $\mathrm{V}$ was inconclusive in this matter. Mean concentrations registered for V were very close to levels reported in urban background areas of Spain (Moreno et al. 2006; Moreno et al. 2010; IDAD 2015). Moreover, measured concentrations of V and Ni were below the respective limit and target values defined in the legislation.

\section{Studying the type of barrier}

To assess the implementation of a barrier upwind from the pile as a measure to block petcoke dispersion, qualitative and quantitative assessments of the petcoke emission for different types of barrier were performed. Qualitative observation was used as a pre-test, prior to the quantitative measurement of petcoke emission for different scenarios. Its main goal was to characterize the dispersion behavior of the petcoke particles, namely in terms of the minimal dispersion velocity and size of the most easily transported particles. Speeds of 1 to $11 \mathrm{~m} \cdot \mathrm{s}^{-1}$ were tested in the Wind Tunnel (WT) with increments of $1 \mathrm{~m} \cdot \mathrm{s}^{-1}$.

The open-circuit wind tunnel used for this study was $12 \mathrm{~m}$ long and had a model test section of 6.5 length $\mathrm{x} 1.5 \mathrm{~m}$ width $\mathrm{x} 1 \mathrm{~m}$ height. It has been previously used for physical modelling of urban flows and air quality in several studies (e.g. Borrego et al. 2007). When applicable, the guidelines proposed by the German Engineering Association for atmospheric boundary layer simulation in wind tunnels were followed for neutral stability conditions. The wind tunnel was designed to generate a uniform flow field through the test section. The atmospheric boundary layer was simulated using a specific setup of turbulence generators and floor roughness elements upstream of the test section. Vertical wind velocity profiles of the simulated atmospheric boundary layer were measured by means of a Pitot tube. The mean velocity profiles, measured at the petcoke pile's location (in the center of the test section), are shown in Figure 3. 


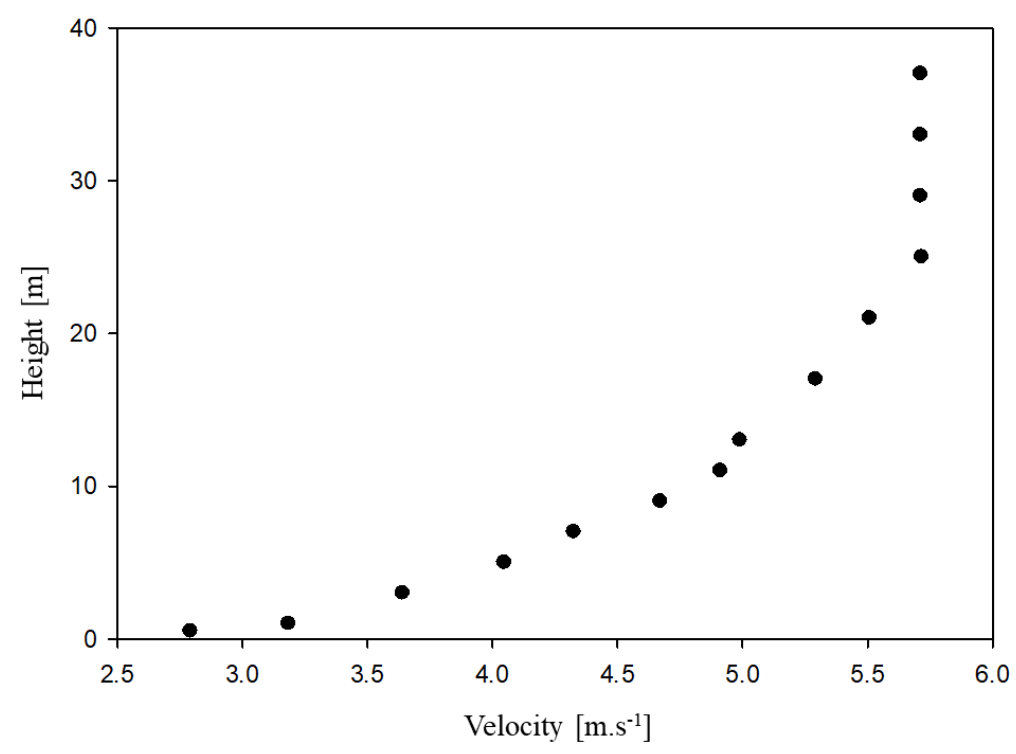

Figure 3. Wind velocity vertical profile above the soil surface.

The obtained wind velocity profiles agreed well with the power law profile when $\alpha=0.19$, which corresponds to the velocity profile of a lagoon area (Avelar et al. 2012).

Petcoke stockpiles were created with the equivalent configuration to the ones in the SBT, simulating discharges of about 10000 tonnes of petcoke. The dimension of each stockpile was scaled at 1/100 to represent a size of $7 \mathrm{~m}$ diameter $\mathrm{x} 10 \mathrm{~m}$ height (see Figure 4). To create the stockpiles for the tests, air-dried low granulometry petcoke samples were used, since these have the greatest dispersion potential.

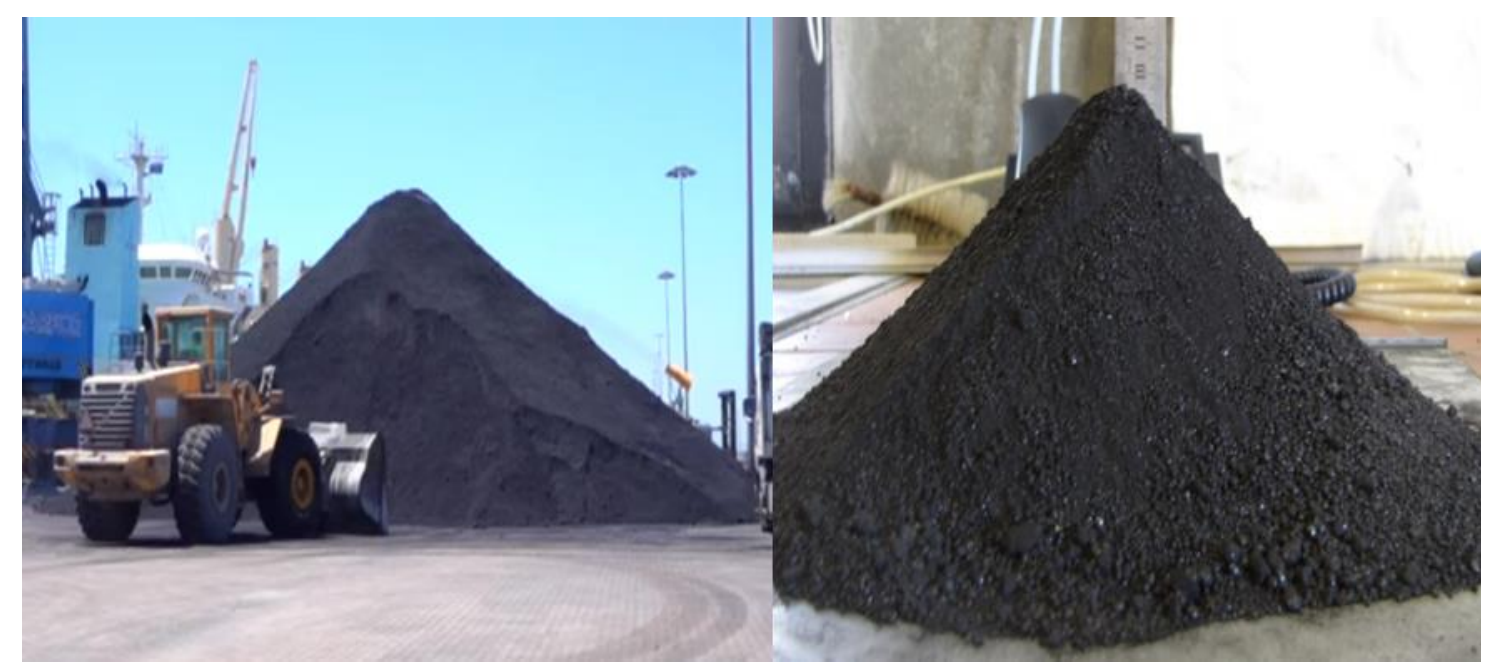

(a)

(b)

Figure 4. (a) Image of a real petcoke stockpile taken at the SBT, (b) Perspective of a typical petcock pile used in the wind tunnel experiments.

For this study, two types of obstacles were investigated: (i) a solid barrier, to simulate the effects of a windbreaker; and (ii) porous barriers, to simulate the effects of pierced fences/shrubs (barrier 
placed at the WT surface, $\mathrm{Z}=0 \mathrm{~m}$ ) or trees (barrier placed $2 \mathrm{~cm}$ above WT surface, corresponding to $\mathrm{Z}=2 \mathrm{~m}$ in the field). Both types of barrier were placed $10 \mathrm{~cm}$ (10 $\mathrm{m}$ in the field) upwind from the petcoke pile, in order to reduce incident wind's intensity.

Figure 5a shows the setup for the experiments performed with the solid barrier, while Figure 5b shows the setup of the experiments performed with the porous barrier (in this photograph, for $\mathrm{Z}=2 \mathrm{~m})$. All tested barriers had a height of $10 \mathrm{~cm}$ (10 $\mathrm{m}$ in the field), which was the same of the petcoke stockpile

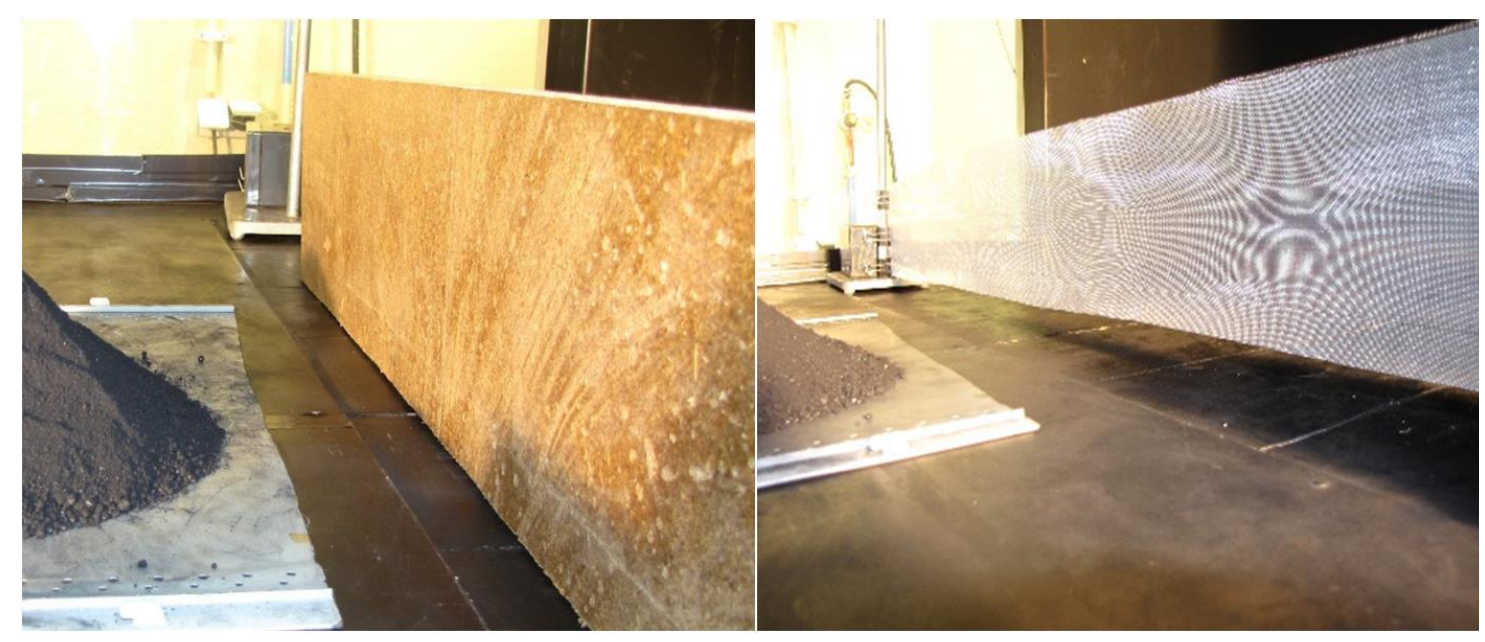

(a)

(b)

Figure 5. (a) Solid and (b) Porous barriers used in the wind tunnel experiments ( $\mathrm{Z}=2 \mathrm{~m}$ ).

For the different barrier setups and the reference scenario, a set of experiments were carried out accounting for different wind directions (N, S and NW) and speeds $\left(3,7\right.$ and $11 \mathrm{~m}^{-\mathrm{s}^{-1}}$ ). As said, these variables represent typical wind conditions and the most critical conditions for the transport of petcoke particles to the residential area. All the experiments had a duration of 10 minutes, which is common in wind tunnel experiments to capture the extremes of the wind speed record (Wainwright and Mulligan 2004). In these experiments, the petcoke pile weight and height were measured before and after the experiment. The emission of petcoke particles was computed from this difference (see Eq. 1), considering that the wind was the only agent responsible for dragging particles out of the pile and transport them downstream (see equation 1). The weight of the petcoke pile before and after the experiment was determined in an electronic balance $( \pm 0.00001$ g precision).

$$
E=\frac{\left(w_{i}-w_{f}\right)}{w_{i}} \quad \text { (Eq. 1) }
$$

where $\mathrm{E}$ are the emissions $(\mathrm{kg}), \mathrm{w}_{\mathrm{i}}$ is the initial weight $(\mathrm{kg})$ and $\mathrm{w}_{\mathrm{f}}$ is the final weight $(\mathrm{kg})$.

Emission reduction was determined comparing the emission obtained in the different scenarios with barrier with the one obtained for a reference scenario with no barrier. 
Table 1 presents the results of the WT experiments for different types of barriers, in terms of reduction of pile height and mass emission. All types of barrier were placed $10 \mathrm{~cm}$ upstream of the pile (10 $\mathrm{m}$ in the field).

Table 1. Petcoke emission reduction and pile height reduction (\%) for the different types of barriers tested, against the reference scenario with no barrier.

\begin{tabular}{lccc}
\hline \multicolumn{1}{c}{ Obstacle } & $\begin{array}{c}\text { Wind velocity } \\
\left(\mathbf{m . s}^{-\mathbf{1}}\right)\end{array}$ & $\begin{array}{c}\text { Pile height } \\
\text { reduction }(\mathbf{\%})\end{array}$ & $\begin{array}{c}\text { Emission reduction } \\
(\mathbf{\%})\end{array}$ \\
\hline \multirow{2}{*}{ Solid barrier } & 3 & $1.05 \pm 0.28$ & $98.78 \pm 0.54$ \\
\cline { 2 - 4 } & 7 & $3.16 \pm 0.13$ & $84.43 \pm 0.79$ \\
\hline Porous barrier & 11 & $4.00 \pm 0.32$ & $85.99 \pm 0.63$ \\
$\mathbf{Z = 0 m}$ & 3 & $1.05 \pm 0.44$ & $93.00 \pm 0.26$ \\
\hline Porous barrier & 7 & $2.11 \pm 0.36$ & $78.44 \pm 0.69$ \\
$\mathbf{Z}=\mathbf{2 m}$ & 11 & $4.12 \pm 0.49$ & $80.61 \pm 0.20$ \\
\hline & 3 & $1.05 \pm 0.33$ & $19.76 \pm 0.86$ \\
\hline
\end{tabular}

All types of barriers tested reduced the transport of petcoke particles, with the solid barrier showing higher efficiency. The largest reduction (about 99\%) was registered for the lower wind velocity. The highest emission reduction obtained with porous barriers was recorded for $3 \mathrm{~m} . \mathrm{s}^{-1}$ winds, when the porous barrier was placed on the wind tunnel surface. For $Z=2 m$, emission reduction increased with higher wind velocity (maximum of approximately $65 \%$ for $11 \mathrm{~m} . \mathrm{s}^{-1}$ wind), because the drag force exerted by the elevated porous barrier was greater in this case than when lower wind speeds were tested. Consequently, the number of edges increased around the barrier, with increasing vorticity, but tended to decrease around the stockpile. The turbulence was highly reduced around the pile for higher wind speeds, which helps explaining these results. The outcome of this set of experiments suggested that a solid barrier upwind from the pile should be chosen as method for reducing petcoke particles' dispersion. The results obtained were in accordance with APA's request, which sought an efficient, low cost solution for the dispersion of particles. The main advantage of this solution was the availability of containers within the harbor, which could be used to build the barrier. In addition, APA decided to alter the dimension of the stockpiles used in the SBT to decrease exposure to wind.

\section{Studying the location and dimensions of the barrier}


After assessing which type of barrier would be more effective, a new set of experiments was conducted in the WT aiming to optimize the position and dimensions of the barrier. Several spatial configurations were tested in the WT for placement of the barrier. Stockpiles were created according to the new guidelines given by the APA (smaller stockpiles), for discharges of about 10000 tonnes of petcoke, which represents the most critical scenario.

The dimension of each studied pile was scaled at 1/127 to represent a size of $95 \mathrm{~m}$ length $\mathrm{x} 33 \mathrm{~m}$ wide $x 7 \mathrm{~m}$ height (see figure 6). Once again, air-dried low granulometry samples were used to simulate the worst case for emission dispersion.

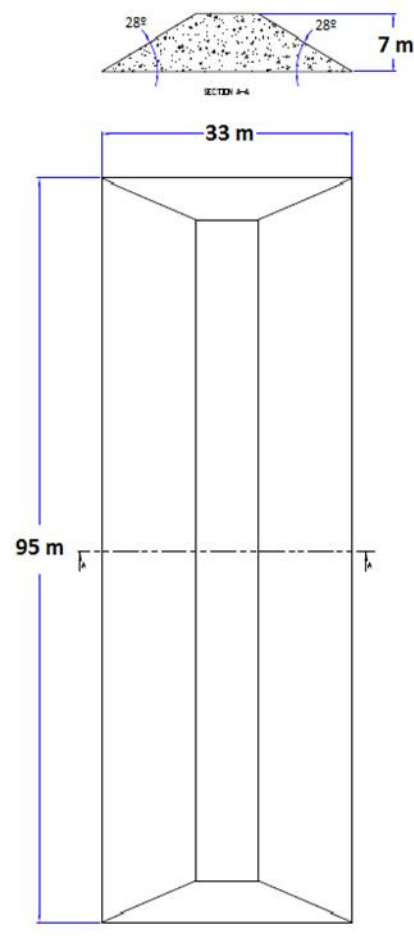

(a)

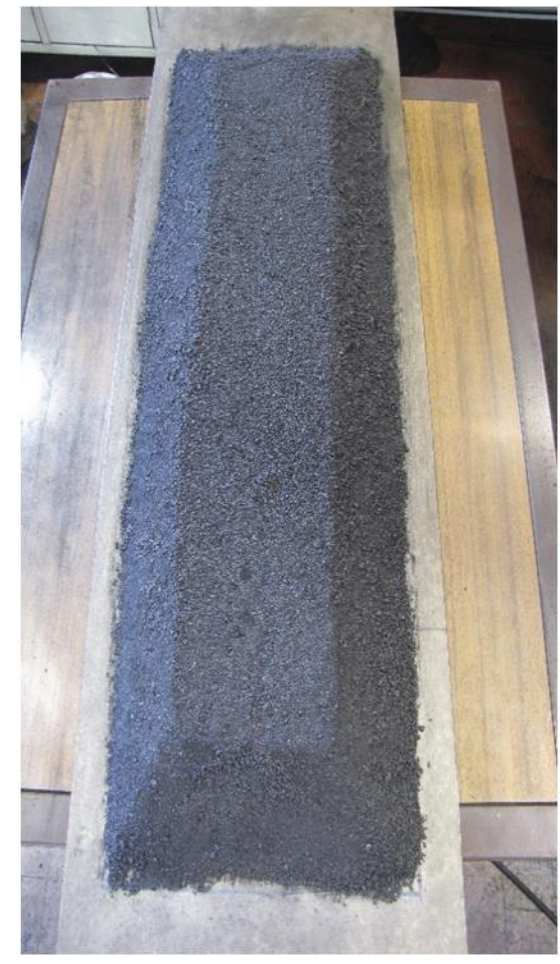

(b)

Figure 6. a) Dimensions of a pile of 10000 tonnes petcoke, according to the guidelines given by the Administration of the Port of Aveiro; b) Petcoke pile scaled at 1/127 for WT experiments.

Experiments were performed considering the typical wind directions registered in Aveiro (see Section 2) to determine the position and dimension of the solid barrier that would lead to the greatest minimization of petcoke dispersion. Different spatial configurations were tested in the WT, as well as a reference scenario, for three wind directions ( $N, S$ and NW), and speeds $(3,7$ and $\left.11 \mathrm{~m} \cdot \mathrm{s}^{-1}\right)$.

The methodology described in Section 3 was followed in these experiments: 10-minute time experiments with measuring of the petcoke stockpile weight and height before and after the 10 minutes time.

In a first step, the behavior of the pile was evaluated in the presence of a single barrier, with: (i) different barrier heights (with 3, 4 and 5 containers in height, corresponding to $5.9 \mathrm{~cm}, 7.9 \mathrm{~cm}$ 
and $9.8 \mathrm{~cm}$, respectively); (ii) different barrier extensions $(74.8 \mathrm{~cm}, 78.5 \mathrm{~cm}, 84.1 \mathrm{~cm}, 107.7 \mathrm{~cm})$; (iii) different positioning of the barrier (upstream and downstream of the pile). From these experiences, the schematic configuration shown in Figure 7(a) was the most efficient configuration. From now on this configuration will be named "configuration A".

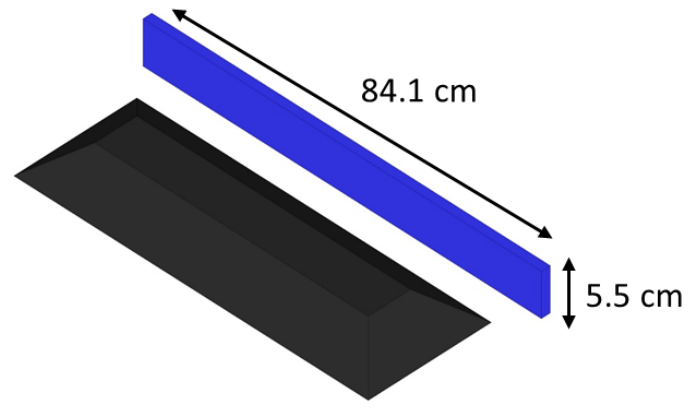

(a)

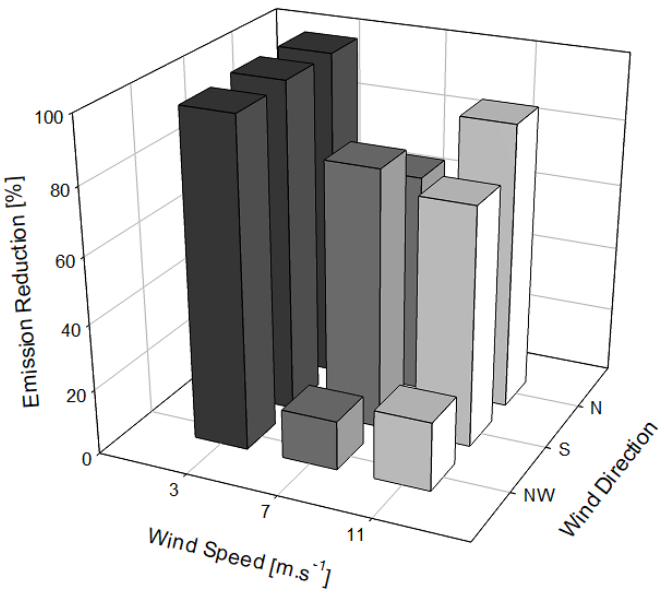

(b)

Figure 7. (a) Schematic representation for the barrier configuration A tested and its dimensions at 1/127 scale (petcoke pile in black, barrier in blue); (b) Petcoke emission reduction (\%), considering different wind conditions.

Results obtained with configuration A showed that using an upstream barrier causes a positive impact on petcoke dust emissions, comparing with placing a barrier downstream. The best results were obtained for an $84.1 \mathrm{~cm}$ length x $5.9 \mathrm{~cm}$ height barrier (1:127 scale).

Placement of the barrier with this configuration proved to be particularly efficient for $\mathrm{N}$ and $\mathrm{S}$ winds, achieving emission reductions of $62 \%$ and $66 \%$ for $7 \mathrm{~m} \cdot \mathrm{s}^{-1}$ wind speed and $79 \%$ and $59 \%$ for $11 \mathrm{~m} . \mathrm{s}^{-1}$ wind speed, respectively. For the NW wind speed scenarios, results were somehow lower than for $\mathrm{N}$ direction: only about $25 \%$ reduction of petcoke emission for wind speed higher than $3 \mathrm{~m} \cdot \mathrm{s}^{-1}$.

In a second step, the focus was on the optimization of a solution that included a secondary barrier, towards NW direction. With this goal, a new set of experiments was performed to test: (i) different positioning of this secondary barrier in relation to the main one (different angles between barriers); (ii) different barrier extensions $(23.3 \mathrm{~cm}, 13.9 \mathrm{~cm}, 18.6 \mathrm{~cm}, 30.0 \mathrm{~cm})$ and (iii) different distances between both barriers. In this set of experiments the distance between the petcoke stockpile and the tested barriers varied as function of the stockpile's dimension: for 6000 tonnes stockpiles, the main barrier was placed $8.4 \mathrm{~cm}$ from the pile (10.7 $\mathrm{m}$ in the field); for $10000 \mathrm{ton}$ stockpiles, the main barrier was distanced from the pile $4.5 \mathrm{~cm}(5.7 \mathrm{~m}$ in the field). These dimensions corresponded to the maximum distance allowed by the APA, to maintain the operational space needed for the movement of trucks and trains. 
Results showed that the use of an upwind solid barrier lead to a very positive impact on petcoke dust emissions, with considerable reduction for both tested configurations (up to $100 \%$ in some cases). The most efficient configuration for the double barrier consisted of a main barrier of 84 $\mathrm{cm}$ length (109 $\mathrm{m}$ in the field) plus a secondary barrier of $23 \mathrm{~cm}$ length (30 $\mathrm{m}$ in the field). This configuration was always at least as efficient as configuration $\mathrm{A}$, and will be named from now on as "Configuration B" (see figure 8 (b)).

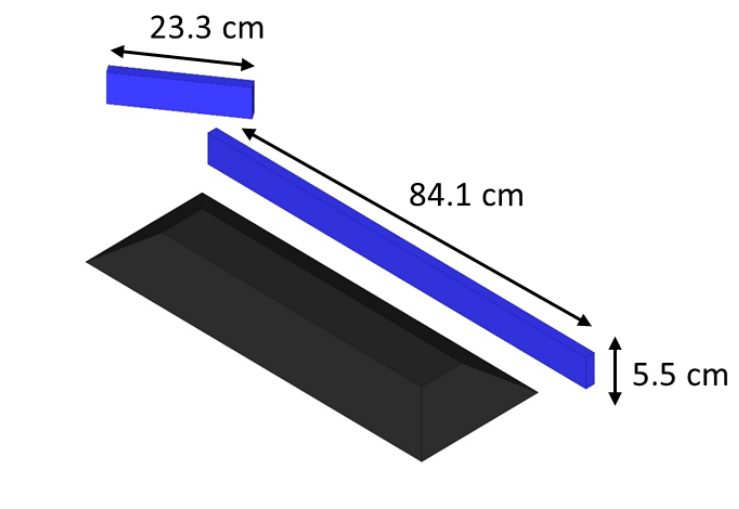

(a)

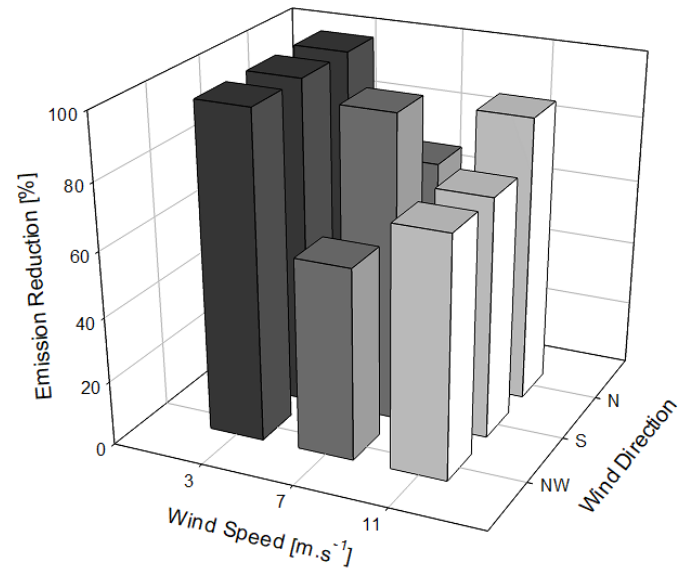

(b)

Figure 8. (a) Schematic representation for the barrier configuration B and its respective dimensions at 1/127 scale (petcoke stockpile in black, barrier in blue); (b) Petcoke emission reduction (\%) obtained with this configuration of barrier

For the highest speed and $\mathrm{N}$ wind direction, which represents one of the most commonly registered conditions in this region, $88 \%$ emission reduction was achieved for the double barrier scenario (B). Moreover, considering this higher wind speed, the best results were achieved exactly for the $\mathrm{N}$ direction wind, which is a very promising result in terms of reducing fugitive particles endangering the residential neighborhood (only $5 \%$ of the pile was dragged by the wind).

Considering that $\mathrm{N}$ and $\mathrm{NW}$ are the most endangering directions for the population, it is especially worth noting that, for the higher speeds tested, the configuration B produced always higher emission reductions then configuration A, proving the importance of adding the secondary barrier. For $11 \mathrm{~m} . \mathrm{s}^{-1} \mathrm{NW}$ winds, the difference between efficiencies was the greatest: configuration $\mathrm{B}$ caused a reduction more than three times higher than configuration A. For S wind, the double barrier also had a positive effect in reducing dispersion of dust particles. 
Figure 9 present some images taken after the wind tunnel experiments, for configurations $A$ and $\mathrm{B}$, for the 3, 7 and $11 \mathrm{~m} \cdot \mathrm{s}^{-1}$ (left to right, respectively), and NW wind conditions.

(a)

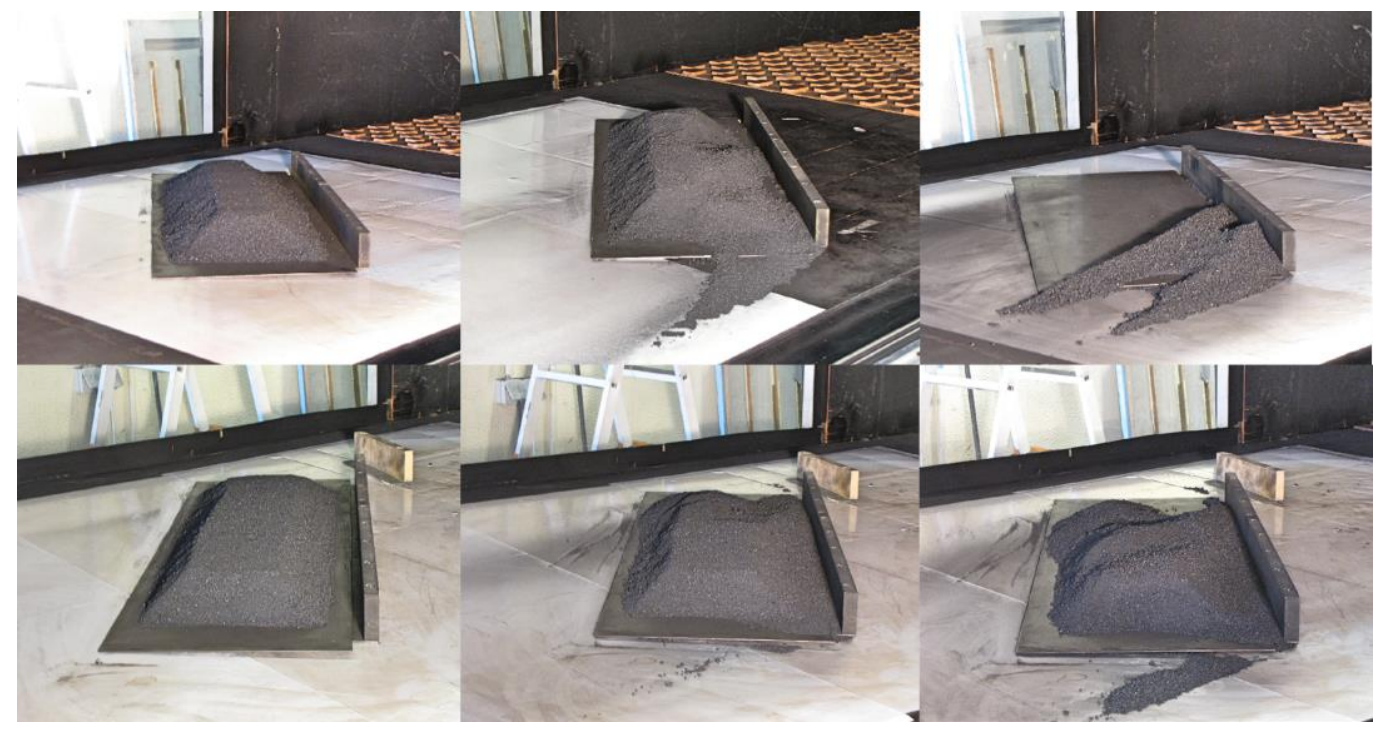

Figure 9. Images of the two barrier configurations tested for NW winds of 3, 7 and $11 \mathrm{~m} \cdot \mathrm{s}^{-1}$ speed (left to right): (a) Southeast perspective of the petcoke pile for barrier configuration A placement experiments; (b) Southeast perspective of the petcoke pile for barrier configuration B placement experiments.

It is worth noting that the described experimental study was performed using very low petcoke moisture contents (always below 1\% weight after air-drying), which leads to higher emissions.

\section{Assessment of local air quality using a CFD model}

A set of numerical simulations were performed using the Computational Fluid Dynamics (CFD) model VADIS (pollutant DISpersion in the atmosphere under VAriable wind conditions), in order to evaluate the effectiveness of a barrier to improve local air quality within the studied harbor area.

VADIS was developed by the University of Aveiro to numerically simulate air pollutants' dispersion in complex urban areas and under unfavorable wind conditions (Borrego et al. 2003; Amorim et al. 2013). The CFD model VADIS consists of two main modules: FLOW and DISPER. FLOW is an Eulerian module, which calculates 3D wind field, turbulent viscosity, pressure, turbulent kinetic energy, and temperature fields affected by a set of obstacles (e.g. buildings, trees) defined in a Cartesian grid. The turbulence closure is performed by means of a first order k- $\varepsilon$ turbulence model, which allows to solve two additional equations to produce turbulent kinetic energy $(\mathrm{k})$ and its dissipation rate $(\varepsilon)$. DISPER module uses the data provided 
by the Eulerian module, namely the wind field, to estimate the 3D concentration field, based on the Lagrangian approach. This methodology assumes that the spatial and temporal dispersion of a pollutant can be conveniently represented by a large enough number of numerical particles released in the flow. The study domain focused on the petcoke pile and the barrier, to better understand its effects on the dispersion of petcoke dust particles, with and without the application of a barrier. This strategy was implemented due to the need to understand and quantify the phenomena that take place in the surroundings of the petcoke pile and the effects that the placement of the proposed barrier may produce.

The computational domain was defined to include the SBT area, where the petcock discharges take place. The domain dimensions were $230 \mathrm{~m}$ x $230 \mathrm{~m}$ x $39 \mathrm{~m}$ (W x L x H), including 3 obstacles representing the pile and the barriers (see Figure 10). A structures mesh is applied with a uniform grid resolution of $1 \mathrm{~m}(\mathrm{dx}=\mathrm{dy}=\mathrm{dz}=1 \mathrm{~m})$. The computational domain processed by the CFD model amounted to 14669 cells occupied by obstacles.

The terrain characteristics were defined in the CFD simulations through the application of the roughness length parameter to each cell of the computational domain. The roughness length was set from $0.005 \mathrm{~m}$, the typical roughness length for a terrain without obstacles and vegetation, to $0.03 \mathrm{~m}$, corresponding to the barriers and the stockpile area (based on the typical roughness length for a terrain with few isolated obstacles). The CFD simulations of the PM10 dispersion were performed by applying zero-normal gradient condition to all boundaries, while for the simulations of the turbulent flow dynamics the boundary conditions were set as periodic.

The inlet profiles were defined based on the theoretical logarithmic vertical profiles given by the equations of Richards and Hoxey (1993), to specify the variation of velocity $\mathrm{U}, \mathrm{k}$ and $\varepsilon$ with height at the inlet boundaries assuming neutral stability conditions:

$$
\begin{aligned}
& U=\frac{u_{*}}{k_{v}} \ln \left(\frac{z+z_{0}}{z_{0}}\right) \\
& k=\frac{u_{*}^{2}}{\sqrt{c \mu}} \\
& \varepsilon=\frac{u_{*}^{3}}{k_{v}\left(z+z_{0}\right)}
\end{aligned}
$$

where $\mathrm{u}^{*}$ is the friction velocity and $\mathrm{k}_{\mathrm{v}}$ is the von Karman's constant set to 0.41 .

The assessment of PM10 concentrations were conducted for an entire day, on an hourly basis. Following the wind tunnel experiments, the stockpile height was kept constant and equal to $7 \mathrm{~m}$ in the CFD simulations, while both solid barriers were defined with $7.5 \mathrm{~m}$ height. The horizontal dimensions of the stockpile were $95 \mathrm{~m} \times 33 \mathrm{~m}$ at the ground level, and $81 \mathrm{~m} \times 7 \mathrm{~m}$ at the top of the pile. The horizontal dimensions of the barriers were set at $109 \mathrm{~m} \mathrm{x} 2.4 \mathrm{~m}$. 


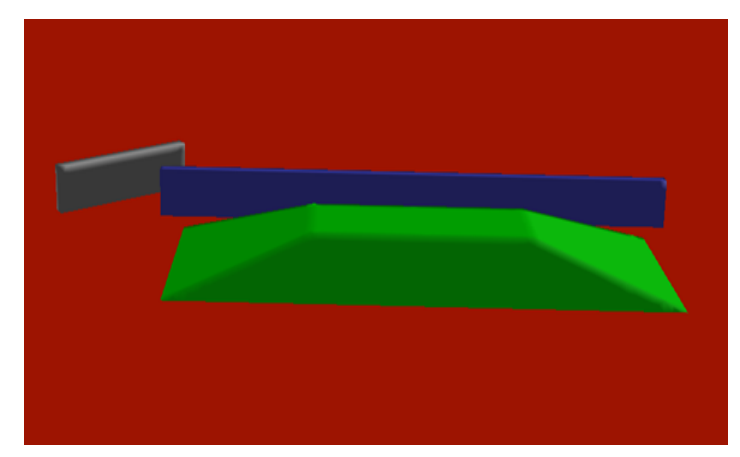

Figure 10. Isometric north perspective of the virtual petcoke pile (green) and barriers (blue and grey).

The numerical simulations required the definition of boundary conditions. In this study, the inlet boundary conditions were defined based on the theoretical logarithmic profile using meteorological data measured at $10 \mathrm{~m}$ height. Meteorological data such as wind speed and direction was measured on the meteorological tower of the University of Aveiro (see section 2), representative of the study area. Statistical analysis of these data allowed the identification of typical atmospheric conditions for the simulation period.

The most critical conditions, in terms of particulate matter emissions, their dispersion and risks for the residential area (wind speed of $7 \mathrm{~m} \cdot \mathrm{s}^{-1}$ and $11 \mathrm{~m} \cdot \mathrm{s}^{-1}$ and the N and NW wind directions) were analyzed with CFD numerical simulations, comparing the baseline, i.e., reference scenario without barrier, and the implementation of the barrier (Configuration B, see Figure 8(a)).

In the stage of pre-processing of the petcoke particles dispersion study, it was necessary to define the distinct emission factors. PM emissions from the pile were computed by the empirical equation 3, which has been developed for operations of loading/unloading of particulate material cargo (USEPA 2015), and where the emission rate (E) depends on the incoming wind velocity $(\mathrm{U})$ and the moisture content $(\mathrm{M})$ of the petcoke, as well as of a multiplication factor $(\mathrm{k})$.

$E=0.0016 \times k \times\left[\frac{(U / 2.2)^{1.3}}{(M / 2)^{1.4}}\right]$

Unloading, over a 1-hour period, of a petcoke pile weighting 10000 tonnes with moisture content of $1 \%$ was considered. For PM10, the multiplication factor that the US Environmental Protection Agency (USEPA) proposes is $\mathrm{k}=0.35$. The emission of petcoke was highly dependent on the moisture content and on the incoming wind velocity. As a result, PM10 emission for loading and unloading such petcoke pile was $8.35 \times 10^{-3} \mathrm{~kg} \cdot \mathrm{s}^{-1}$ for $7 \mathrm{~m} \cdot \mathrm{s}^{-1}$ wind and $1.48 \times 10^{-2} \mathrm{~kg} \cdot \mathrm{s}^{-1}$ for $11 \mathrm{~m} \cdot \mathrm{s}^{-}$ ${ }^{1}$ wind. 
The first simulation domain only included the petcoke pile, corresponding to the reference situation of petcoke discharge and storage in the SBT. The second domain comprised the petcoke pile and the most efficient barrier, with dimensions and location according to Section 4.

Specific cases of $7 \mathrm{~m} \cdot \mathrm{s}^{-1}$ wind speed for NW and N wind direction are discussed here. Figures 11 (the reference scenario without barrier) and 12 (the mitigation scenario, corresponding to the implementation of the barrier) present the horizontal contour of PM10 concentration fields at 2.5 $\mathrm{m}$ height, for configuration $\mathrm{B}$.

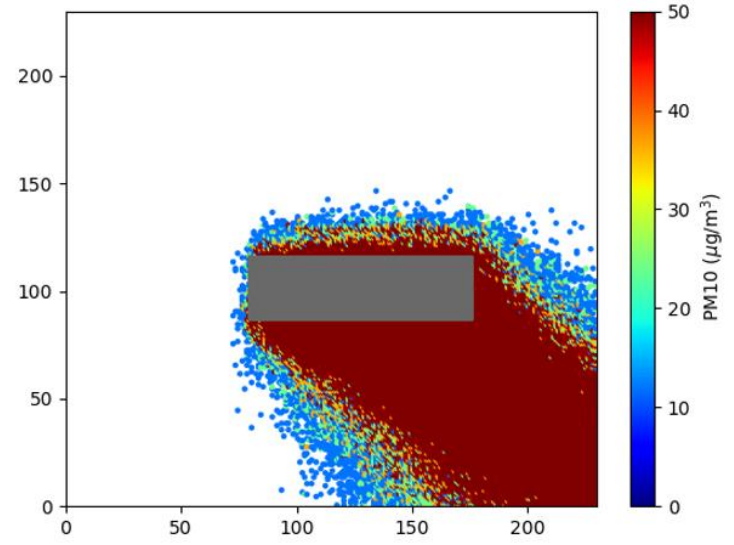

(a)

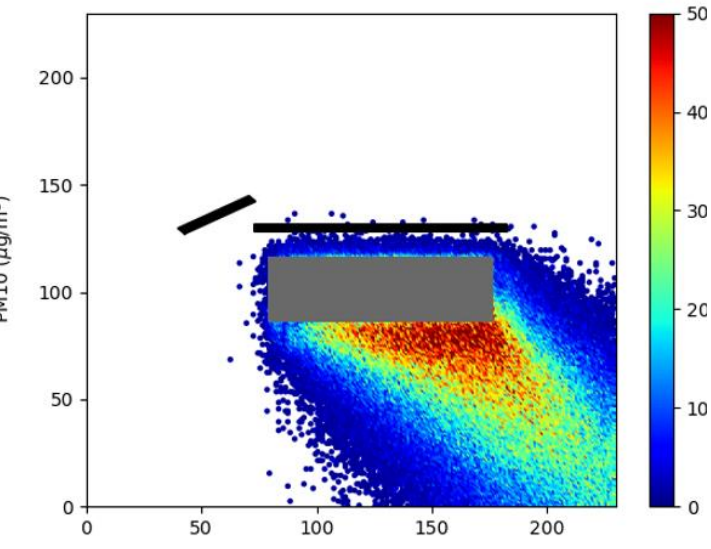

(b)

Figure 11. Horizontal contour of PM10 concentration, for an inflow wind blowing from NW with a wind speed of $7 \mathrm{~m} \cdot \mathrm{s}^{-1}$ : (a) CFD simulation without the barrier; (b) CFD simulation with the barrier (the two implemented barriers are represented in black).

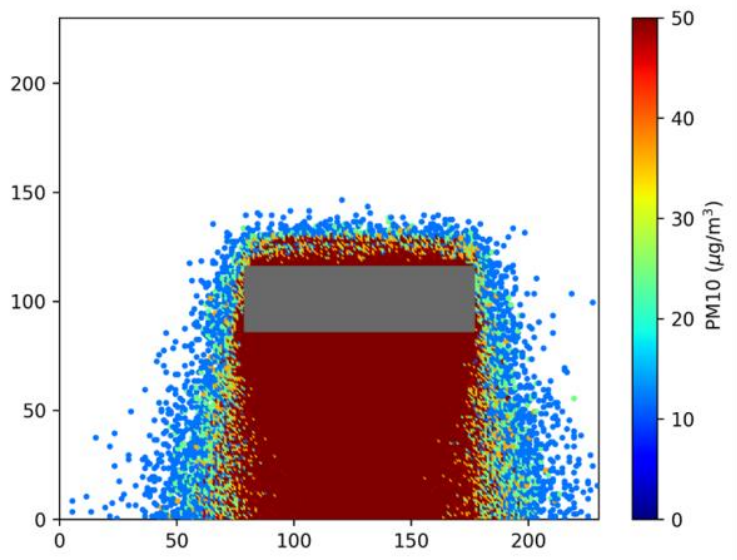

(a)

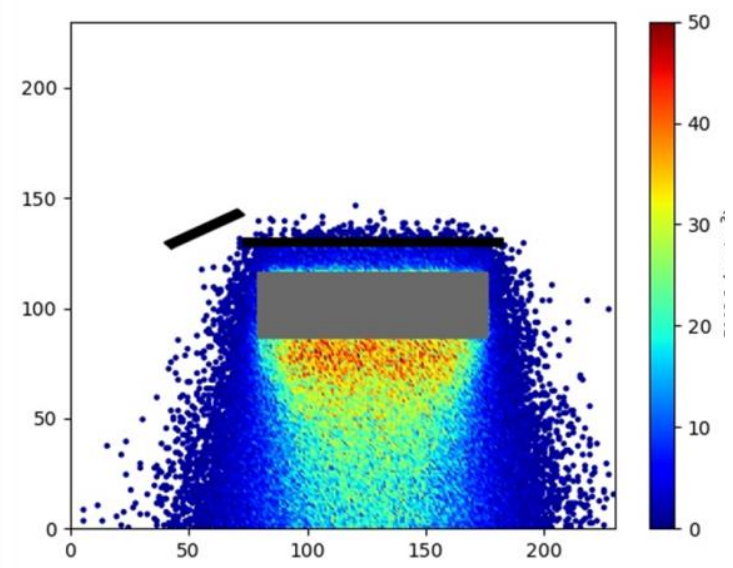

(b)

Figure 12. Horizontal contour of PM10 concentration field for an inflow wind from $\mathrm{N}$ and a wind speed of $7 \mathrm{~m} \cdot \mathrm{s}^{-1}$ : (a) CFD simulation without the barrier; (b) CFD simulation with the barrier. 
The highest PM10 concentrations were found near the petcoke stockpile, the emission source of dust. The implementation of the barrier produced a positive effect for both wind directions, reducing the dust particles in the surrounding area of the pile. The maximum PM10 concentrations in the reference scenario were about $300 \mu \mathrm{g} \cdot \mathrm{m}^{-3}$, while in the mitigation scenario, with the implementation of the barriers, the maximum concentration of PM10 were only $50 \mu \mathrm{g} \cdot \mathrm{m}^{-3}$.

For $\mathrm{N}$ and NW wind, the barrier also had a positive effect in reducing the dust particles in the surroundings of the pile. The highest PM10 concentrations were once again found near the petcoke pile, which is the most important source of emissions.

Table 2 presents the reduction of PM10 concentrations for a wind blowing from N and NW, for 7 and $11 \mathrm{~m} . \mathrm{s}^{-1}$ speeds.

Table 2. Reduction of PM10 concentrations obtained within the computational domain with the mitigation scenario.

\begin{tabular}{ccc}
\hline Direction & Wind speed $\left(\mathrm{m} . \mathrm{s}^{-1}\right)$ & Reduction concentration (\%) \\
\hline \multirow{2}{*}{$\mathrm{N}$} & 7 & 81 \\
& 11 & 88 \\
\hline \multirow{2}{*}{$\mathrm{NW}$} & 7 & 75 \\
& 11 & 79 \\
\hline
\end{tabular}

For the tested scenarios, results indicated an effective improvement of air quality due to the implementation of the proposed barrier. Numerical results showed that using an upwind barrier lead to a very positive impact on reduction PM10 concentration, with decrease up to $88 \%$ in the optimized configurations.

The overall reduction of PM10 concentrations in the proposed mitigation scenarios were due to the flow blocking effect promoted by the barriers. The low wind speed region created by the flow deceleration upstream from the barriers prevents the interaction with the stockpiles, protecting it from the wind erosion, and minimizes the emission of particles.

The higher concentrations within the domain were recorded for the NW wind scenario. However, since these concentrations are found immediately downstream of the pile, they do not represent a concern other than for the workers at that location (e.g, workers on the ship).

\section{CONCLUSIONS}

This paper focused on the development of a feasible solution to reduce petcoke emissions from a Portuguese harbor (Port of Aveiro), which could be endangering the population and dwellings of the surrounding urban area. 
The use of different barriers, positioned downstream and upstream of the petcock pile, resulted in reductions in particulate emissions compared to the reference scenario. Upstream placement was the most efficient solution. The barrier typology that led to the largest reductions in particle emissions was the solid barrier, which blocked more efficiently the passage of wind to the pile. Results showed that placing a double barrier with the position and configuration named as B would be the most efficient solution to reduce petcoke dust emissions for the most critical wind directions concerning the residential areas ( $\mathrm{N}$ and $\mathrm{NW})$.

Results from the numerical modelling for the optimal configuration found with WT simulations showed good agreement with the trends observed with the physical modelling. Modelling results also indicate a significant reduction of fugitive particles with the placement of the barrier, confirming the wind tunnel conclusions. The optimized barrier has been implemented in the field and monitoring campaigns are currently being carried out to assess its effectiveness.

The methodology discussed in this study allows quantifying the impacts of harbor activity in its surroundings, independently on its location. This way, the procedure described in this paper to assess the effectiveness of a barrier as a solution to mitigate fugitive dust emissions can be an effective methodology to implement in other harbor with similar air quality issues.

\section{ACKNOWLEDGEMENTS}

The authors wish to thank the financial support of FEDER through the COMPETE Programme and the national funds from FCT - Science and Technology Portuguese Foundation for financing the AIRSHIP project (PTDC/AAG-MAA/1581/2014), CESAM (UID/AMB/50017 - POCI-010145-FEDER-007638), and also for the PhD grant of S. Sorte (SFRH/BD/117164/2016). The authors are also grateful to the Institute of Environment and Development, and to the Administration of the Port of Aveiro for promoting the work and allowing the results to be disseminated.

\section{REFERENCES}

Avelar A, Brasileiro F, Marto A, Maricotto E, Fisch G, Faria A (2012) Wind Tunnel Simulation of the Atmospheric Boundary Layer for Studying the Wind Pattern at Centro de Lançamento de Alcântara. J Aerosp Technol Manag 4:463-473. https://doi.org/10.5028/jatm.2012.04044912

Amorim JH, Rodrigues V, Tavares R, Valente J, Borrego C (2013) CFD modelling of the aerodynamic effect of trees on urban air pollution dispersion. Sci Total Environ 461-462:541551. https://doi.org/10.1016/j.scitotenv.2013.05.031

Baker LF, Ciborowski JJH, MacKinnon MD (2012) Petroleum coke and soft tailings sediment in constructed wetlands may contribute to the uptake of trace metals by algae and aquatic invertebrates. Sci Total Environ 414:177-186. https://doi.org/10.1016/j.scitotenv.2011.10.011

Balakrishnan K, Ganguli B, Ghosh S, Sambandam S, Roy S, Chatterjee A, (2013) A spatially disaggregated time-series analysis of the short-term effects of particulate matter exposure on 
mortality in Chennai, India. Air Qual Atmos Health 6, 111-121. https://doi.org/10.1016/j.atmosenv.2014.04.057

Borrego C, Tchepel O, Costa AM, Amorim JH, Miranda AI (2003) Emission and dispersion modelling of Lisbon air quality at local scale. Atmos Environ 37:5197-5205. https://doi.org/10.1016/j.atmosenv.2003.09.004

Borrego C, Costa AM, Amorim J, Santos P, Sardo J, Lopes M, Miranda AI (2007) Air quality impact due to scrap-metal handling on a seaport: a wind tunnel experiment. Atmos Environ 41:6396-6405. https://doi.org/10.1016/j.atmosenv.2007.01.022

Caruso JA, Zhang K, Schroeck NJ, McCoy B, McElmurry SP (2015) Petroleum coke in the urban environment: A review of potential health effects. Int J Environ Res Public Health 12:6218-6231. https://doi.org/10.3390/ijerph120606218.

Contini D, Gambaro A, Donateo A, Cescon P, Cesari D, Merico E, Citron M (2015) Inter-annual trend of the primary contribution of ship emissions to PM2.5concentrations in Venice (Italy): Efficiency of emissions mitigation strategies. Atmos Environ 102:183-190. https://doi.org/10.1016/j.atmosenv.2014.11.065

CRS (Congressional Research Service) (2013) Petroleum Coke: Industry and Environmental Issues. Washington D.C., U.S.A.

Dourson ML, Chinkin LR, MacIntosh DL, Finn JA, Brown KW, Reid SB, Martinez JM (2016) A Case Study of Potential Human Health Impacts from Petroleum Coke Transfer Facilities. J Air Waste Manag Assoc 66:1061-1076. https://doi.org/10.1080/10962247.2016.1180328

EEA (European Environment Agency) (2013) Air quality in Europe - 2013 report. Copenhagen, Denmark

ESPO (European Sea ports Organisation) (2013) Top Environmental Priorities of European Ports for 2013. An Analysis Taking Port Size and Geography into Consideration. Brussels, Belgium

USEPA (United States Environmental Protection Agency) (2011) Exposure Factors Handbook: 2011 Edition. Washington D.C., U.S.A.

USEPA (United States Environmental Protection Agency) (2015) Emissions Estimation Protocol for Petroleum Refineries. Research Triangle Park, North Carolina

Grahame T, Schlesinger R (2010) Cardiovascular health and particulate vehicular emissions: a critical evaluation of the evidence. Air Qual Atmos Health 3:3-27. https://doi.org/10.1007/s11869-009-0047-x

Guttikunda S, Goel R, Mohan D, Tiwari G, Gadepalli R (2015) Particulate and gaseous emissions in two coastal cities: Chennai and Vishakhapatnam, India. Air Qual Atmos Health 8:559-572. https://doi.org/10.1007/s11869-014-0303-6

Healy RM, O'Connor IP, Hellebust S, Allanic A, Sodeau JR, Wenger JC (2009) Characterisation of single particles from in-port ship emissions. Atmos Environ 43:6408-6414. https://doi.org/10.1016/j.atmosenv.2009.07.039

IDAD (Institute of Environment and Development) (2015) Avaliação da Qualidade do Ar na Envolvente do Porto de Aveiro, IDAD report No. R074.15-14/05.05, Aveiro, Portugal 
Isakson J, Persson T, Lindgren E (2001) Identification and assessment of ship emissions and their effects in the harbour of Göteborg, Sweden. Atmos Envirot 35:3659-3666.

Keil RG, Neibauer J, Biladeau C, van der Elst K, Devol AH (2016) A multiproxy approach to understanding the "enhanced" flux of organic matter through the oxygen deficient waters of the Arabian Sea. Biogeosciences 13:2077-2092. https://doi.org/10.5194/bg-13-2077-2016

McKee RH, Herron D, Beatty P, Podhasky P, Hoffman GM, Swigert J, Lee C, Wong D (2014) Toxicological Assessment of Green Petroleum Coke. Int J Toxicol 33:156S-167S. https://doi.org/1177/1091581813504187

Moreno T, Querol X, Alastruey A, Viana M, Salvador P, Campa A. S, Artiñano B, Rosa J, Gibbons W (2006) Variations in atmospheric PM trace metal content in Spanish towns: Illustrating the chemical complexity of the inorganic urban aerosol cocktail. Atmos Environ 40: 6791-6803. https://doi.org/10.1016/j.atmosenv.2006.05.074

Moreno T, Querol X, Alastuey A, Rosa J, Campa AM, Minguillón M, Pandolfi M, GonzálezCastanedo Y, Monfort E, Gibbons W (2010) Variations in vanadium, nickel and lanthanoid element concentrations in urban air. Sci Total Environ 408:4569-4579. https://doi.org/10.1016/j.scitotenv.2010.06.016

Novak L, Bizjan B, Pražnikar J, Horvat B, Orbanić A, Sirok B (2015) Numerical Modeling of Dust Lifting from a Complex-Geometry Industrial Stockpile. J Mech Eng 61:321-631. http://dx.doi.org/10.5545/sv-jme.2015.2824

Puttaswamy SJ, Nguyen HM, Braverman AJ, Hu X, Liu Y (2014) Statistical data fusion of multisensor AOD over the continental United States. Geocarto Int 29:48-64. https://doi.org/10.1080/10106049.2013.827750

Richards PJ, Hoxey R (1993) Appropriate boundary conditions for computational wind engineering models using the k-e turbulence model. Journal of Wind Engineering and Industrial Aerodynamics 46-47:145-153. https://doi.org/10.1016/0167-6105(93)90124-7

Roskill (Roskill Information Services Head Office) (2015) Petroleum Coke: Global Industry, Markets \& Outlook. https://roskill.com/product/petroleum-coke-global-industry-marketsoutlook-7th-edition-2015/. Accessed in 15 December 2016

Salnikow K, Donald SP, Bruick RK, Zhitkovich A, Phang JM, Kasprzak KS (2004) Depletion of intracellular ascorbate by the carcinogenic metals nickel and cobalt results in the induction of hypoxic stress. J Biol Chem 279:40337- 44. https://doi.org/10.1074/jbc.M403057200

Schrooten L, Vlieger ID, Panis LI, Styns K, Torfs R (2008) Inventory and forecasting of maritime emissions in the Belgian sea territory, an activity-based emission model. Atmos Environ 42:667676. https://doi.org/10.1016/j.atmosenv.2007.09.071

Song S (2014) Ship emissions inventory, social cost and eco-efficiency in Shanghai Yangshan port. Atmos Environ 82:288-297. https://doi.org/10.1016/j.atmosenv.2013.10.006

Sorte S, Lopes M, Rodrigues V, Leitão J, Monteiro A, Ginja J, Coutinho M, Borrego C (2018) Measures to Reduce Air Pollution Caused by Fugitive Dust Emissions From Harbour Activities. International Journal of Environmental Impacts. 1:115-126. https://doi.org/10.2495/EI-V1-N2$115-126$

Wainwright J, Mulligan M (Eds.) (2004) Environmental Modelling: Finding Simplicity in Complexity. Wiley, Chichester 